\title{
Mihin ympäristökeskustelu tulee kohdentaa?
}

\author{
Yrjö Haila
}

Ympäristönsuojeluongelmat nousivat laajasti yleiseen tietoisuuteen ja keskusteluun 1960luvulla; kansainvälisenä herätyskirjana voidaan tässä yhteydessä syystä pitää Rachel Carsonin teosta "Silent Spring" (suomennettu nimellä Hiljainen kevät), joka ilmestyi Yhdysvalloissa vuonna 1962. Keskutelu on saanut uusia piirteitä, joiden taustana on tietenkin itse ongelmien kärjistyminen. Tarkastelen seuraavassa aluksi kahta keskustelun ajankohtaista piirrettä: kuluneen kesän ja syksyn aikana Suomessa käytyä väittelyä kansallispuistoista, sekä länsimaisten "ekologiapuolueiden" esiintymistä. Nämä molemmat nostavat esiin joukon kysymyksiä, jotka koskevat ympäristöongelmien perusteita, joihin vastaamisesta on kyse ympäristökeskustelun lähtökohdista.

\section{Kansallispuistokeskustelu}

Kauppalehti kirjoitti pääkirjoituksessaan 7. 10. 1977 seuraavasti: "Komitean esittämiin alueisiin olisi syytä tehdä suurin muutos kaukaisten kansallispuistojen osalta, sillä suunnitellussa mitassa niillä ei riitä katselijoita eli käyttöä. Vain intohimoinen luonnonkävijä haluaa käydä useammassa kuin parissa kolmessa samanlaisessa. Selvästi toisistaan poikkeavia kansallispuistoehdokkaita ei näet ole kovinkaan monta erilaista tyyppiä." Kauppalehti, talouselämän äänenkannattaja, arvioi näin kansallispuistojen tarvetta esittäen perustelunaan uudenlaisen "näkemyksen" maamme alkuperäisen luonnon vaihtelevuudesta; Suomen syrjäseutujen luonto on yksitoikkoista ja siksi luonnonsuojelun tarve on vähäinen. Väitteessä ei ole mitään perää. Mutta tämä ei olekaan sinänsä olennaista. Mielenkiintoista on perustelujen logiikka: Etsitään luonnontieteelliseltä vivahtavia syitä sille, että kansallispuistoja ei tarvita; pelkät taloudelliset intressit - jotka ovat taustalla - eivät Kauppalehden mielestä riitä "kumoamaan" riittävän vakuuttavasti luonnonsuojelun välttämättömyyttä.

Kauppalehden perustelujen logiikka osana kansallispuistokomitean esityksen herättämää keskustelua on paljastanut entistä selvemmin ympäristönsuojelun rintamat. Tapahtumien kulku on syytä lyhyesti kerrata.

Kansallispuistokomitea asetettiin tammikuussa 1974. Sen tehtävänä oli valmistella kansainvälisiä - mm. YK:n elinten sekä kansainvälisen luonnonsuojeluliiton IUCN:n vahvistamia suosituksia vastaava esitys maamme luonnonsuojelualueiden kehittämiseksi. Komitean työ on ollut inventoivaa asiantuntijatyötä ja se on päätynyt esitykseen, jota voidaan syystä pitää perusteltuna runko-ohjelmana alkuperäisen luonnon suojelulle Suomessa.

Komitean esityksen julkistamisen jälkeen alkoi nopea tapahtumasarja: Muutaman viikon aikana aloitettiin hakkuu- tai ojitustyöt noin kahdessakymmenessä kohteessa, joita komitea esitti suojeltaviksi. Nopeimmin reagoi Kymin Oy, joka käynnisti "aavistuhakkuut" omistamillaan suojeluesityksiin sisältyvillä metsäalueilla PohjoisKymenlaaksossa jo ennen mietinnön julkistamista. Toimenpiteet saivat tiedotusvälineissä laajaa julkisuutta.

Suomalainen luonnonsuojelu oli kärkevämmin kuin koskaan aikaisemmin törmännyt yhteiskunnallisiin rajoituksiin. Luonnonrikkaudet ovat yksityisessä hallinnassa ja niiden käyttö määrätään omistajiensa etujen perusteella. Reaktion takana olivat suurmaanomistajia ja metsäteollisuutta edustavat piirit. On ilmeistä, että voimakas reaktio ei ollut yksinomaan luonnonvoimainen: Haluttiin saada voimakkaasti leviämään julkisuuteen sellainen käsitys, että komitean valmistelema suojelusuunnitelma on kerta kaikkiaan mahdoton, että sen toteuttamiseen ei kerta kaikkiaan tulla suostumaan.

Kansallispuistoesitystä on voimakkaasti arvosteltu myös toiselta taholta. Useissa niistä kunnista, joita esitys läheisimmin koskee, vallit- 
see yli $10 \%$ :n työttömyys. Metsätöiden väheneminen pahentaisi luonnollisesti tilannetta entisestään. Useilla alueilla Pohjois-Pohjanmaalla ja Lapissa nousikin vaatimuksia, että suojeluesityksen mukaiset hakkuukiellot on eräissä kohteissa kumottava, jotta vältettäisiin työttömyystilanteen välitön vaikeutuminen. Vaatimuksia tu, ki myös mm. Pohjois-Pohjanmaan luonnonsuojeluyhdistys.

Onko syntynyt tilanne tulkittava siten, että maamme alkuperäisen luonnon suojeleminen on kaikkien väestöryhmien etujen vastaista? Ei suinkaan. On tehtävä selvä ero maanomistajien ja metsätyöläisten vastalauseiden välillä. Kyseessä ovat vastakkaiset yhteiskunnalliset intressit. Toisessa on kyse voitonsaalistuksesta, toisessa elinehtojen perustekijän, työmahdollisuuksien säilyttämisestä. Tarkasteltakoon metsätöiden työvoimakehitystä kuvaavaa tilastoa: Markkinahakkuissa oli oman tilan ulkopuolella hakkuukautena 1965/66 työllistettynä 72300 henkeä, hakkuukautena 1975/76 vastaava luku oli 26000 . Metsäteollisuuden omien arvioiden mukaan hakkuutyövoiman tarve tulee vuoteen 1985 mennessä alenemaan 15 000:lla. Mikäli tämä arvio toteutuu, tulee siis metsätöiden työvoimatarpeessa tapahtuneeksi kahdessakymmenessä vuodessa lasku noin kuudesosaan. Työvoiman vähenemisen yksinomaisena syynä on metsätöiden koneistaminen ja rationalisointi, jota metsäyhtiöt ovat toteuttaneet alentaakseen hakkuukustannuksia.

Kansallispuistokomitean esityksen merkitsemä työvoiman vähennys metsätöissä olisi komitean arvion mukaan 490 työpaikkaa. Tästä valtaosa koskisi Pohjois-Suomea, missä välitön vaikutus pelkästään Lapin läänin alueella arvioitiin noin 100 työpaikan suuruiseksi.

Luvut osoittavat, että metsätöiden työllisyystilanteen ja luonnonsuojelutavoitteiden välillä ei voi olla syy-yhteyttä. Sen sijaan työttömyystilanteen paheneminen ja luonnonsuojelun vaarantuminen palautuvat samaan tekijään: Talousmet- sien käyttöä ohjaavat tuotantovälineet omistavien kapitalistien voittoedut. Kansallispuistojen perustamisesta käyty keskustelu on nostanut temppelin harjalle maamme luonnonrikkauksien yksityiset haltijat.

\section{Ekologismi}

Kansainvälisessä ympäristökeskustelussa silmiinpistävin muutos on ollut lehdistössä yhä laajempaa palstatilaa saavien "ekologiapuolueiden" esiintyminen eräissä kapitalistisissa maissa. Näiden äänenkannattajana toimivan englantilaisen "Ecologist" -lehden päätoimittaja Edward Goldsmith on lehden numerossa 10/75 esitellyt puolueiden toimintaa. ${ }^{1}$ Englannissa toimiva "People Party" ja ranskalainen "Ecologie et Survie" ovat suurimmat, niiden vaalimenestys vuosikymmenen alussa oli noin 1.3 \% annetuista äänistä (Ranskan kunnallisvaaleissa 1977 sikäläinen puolue sai useissa kaupungeissa peräti 7-9 \% äänistä). Lisäksi on toiminnassa Uudessa Seelannissa "Values Party", Australiassa "Austria Party" ja Tasmaniassa "United Tasmanian Party".

Goldsmithin tulkinnan mukaan puolueet ovat poliittinen ilmaus laajemmasta liikkeestä, joka on syntynyt "vastavaikutuksena teolliseen yhteiskuntaan ja sen arvoihin". Liike "hylkää teollisen maailman siksi, että tämä on keskinkertainen, ruma, luonnoton ja tekopyhä - koska tämä toisinsanoen ei kykene tyydyttämään perustavia sosiaalisia, esteettisiä ja henkisiä tarpeita". Teollisen maailman mukana lennätetään sivuun "nykyaikainen tiede keinona hankkia tietoa", "nykyaikainen teknologia" sekä "teollisesti valmistetut kulutustavarat". Liike esiintyy Goldsmithin mukaan monissa muodoissa, syrjään vetäytymisenä, paluuna maalle, uusien elämäntapo-

1. E. Goldsmith, The two Ecologies, The Ecologist 5: $362-367$. 
jen etsintänä. Kaiken perusteluna on Ekologia suurella E:1lä - "toinen" ekologia erotukseksi "tavanomaisesta" ekologiasta: "Ainoastaan he ovat omaksuneet arvojärjestelmän, jota voidaan todella pitää ekologisena - siinä mielessä, että ainoastaan sellainen yhteiskunta, joka on omaksunut nämä arvot, voi välttää ympäristönsä järjestelmällisen ja kiihtyvän tuhoutumisen."

Goldsmithin esittelemän ajattelutavan perustana on väite, että teollinen yhteiskunta on ehdottomassa ristiriidassa luonnon kanssa: "Todellakin, teollinen yhteiskunta, joka on luonnollinen tulos liberalismin, individualismin, materialismin ja ekonomismin ihanteista, tuhoaa välttämättä itsensä ja ekosysteemin, jossa se toimii; tämä on ilmeistä yhteiskunnan luonteen perusteella." Teollinen yhteiskunta kehittää materian uuden organisaation "teknosfäärin", joka korvaa elävien organismien muodostaman biosfäärin. Edellinen voi laajeta seurauksena jälkimmäisen kustannuksella. Teollisuuden kehityksen seurauksena on ehdottomasti määritelmän mukaan elollisen luonnon rappeutuminen. Tämän johdosta vallitsevan ajattelun ja nykyaikaisen tieteen tilalle on otettava kokonaan uusi ajattelutapa, jonka keskeinen piirre on se, että maailmaa on tarkasteltava kokonaissysteeminä; kun tämä tehdään, "vallitsevien arvojen täydellinen kelvottomuus tulee täysin ilmeiseksi".

Ekologian väitetään osoittaneen kaiken tämän — siksi nimitys "ekologismi" on paikallaan tăssä yhteydessä jos missään. Kriittinen väite on se, ettă teollinen yhteiskunta on välttämättä ristiriidassa luonnon ekologisten lainalaisuuksien kanssa. "Ekologisten" ohjelma on kova: vaaditaan koko nykyaikaisen kulttuurin hylkäämistä teknologioineen ja tieteineen. Edellä esiteltyjen Goldsmithin ajatusten arvioiminen edellyttää kokonaiskäsitystä ihmisen ja luonnon vuorovaikutussuhteen periaatteista. Goldsmith esittää ekologian ehdottomana, ihmisen toimintaa kahlitsevana pakkolakina. Onko tämä itsestään selvää?

\section{Mikä on ekologinen kriisi?}

Niin kaukana kuin Suomen kansallispuistokeskustelu ja Englannin ekologistinen ajattelu näennäisesti ovatkin toisistaan, niillä on itse asiassa yhteinen nimittäjä: Ympäristöongelmien yhteiskunnallinen luonne on tullut vastaansanomattoman selväksi. Mutta tähän tosiasiaan reagoidaan hyvin eri tavoin.

Keskustelun sanavarastoon ovat vakiintuneet käsitteet ekologinen kriisi, ympäristökriisi ja ekokatastrofi, jotka tarkoittavat kaikki sitä, että ympäristöongelmat ovat vakavassa, kärjistyvässä ja ihmiskunnan tulevaisuutta uhkaavassa vaiheessa. Dramaattisin termi on "ekokatastrofi", jonka esitti amerikkalainen biologi Paul Ehrlich vuonna 1969 ilmestyneessä artikkelissaan "EcoCatastrophe!" Artikkeli on ilmestyskirjamainen ennustus elollisen luonnon täydellisestä tuhoutumisesta; tästä antaa jo alkulause aavistuksen: "Valtameret kuolivat myöhäiskesällä vuonna 1979, tämä tapahtui jopa nopeammin kuin biologit olivat odottaneet. . .". Samaa linjaa edusti USA:ssa huhtikuussa 1970 järjestetty "Maan päivă"; laaja julkisten keskustelujen, mielenosoitusten ja kokousten sarja, jonka teemana oli ympäristökriisi. Mitä käsite "ympäristökriisi" tarkoittaa? Amerikkalainen biologi Barry Commoner julkaisi vuonna 1971 "Maan päivän" innoittamana kirjan Ympyrä sulkeutuu, jossa hän erittelee päivän merkitystä seuraavasti: "Maan päivä ja siihen liittyvä julkisuuden, julistusten ja ennustelujen tulva yllätti useimmat ihmiset. . . Eniten minua yllättivăt lukuisat itsevarmat selitykset kriisin syistä ja parannuskeinoista. . Maan päivän jälkeen yritin löytää jotakin mieltä sen tuottamien vastakkaisten neuvojen sekasorrosta. . Vakuutuin maan päivänä siitä, että ympäristökriisin syiden ja mahdollisten hoitota-

2. P. Ehrlich, Eco-Catastrophe!, Ramparts, syyskuu 1969; julkaistu myös teoksessa: G. \& R. Love (toim.): Ecological Crisis, New York 1970. 
pojen syvempi yleinen ymmärtäminen oli välttämätöntä. Se on juuri tämän kirjan tarkoitus. Tämä kirja on yritys selvittää, mitä ympäristökriisi merkits e e."

Commonorin esittämä vaatimus ympäristökriisin syiden täsmällisestä analyysistä on vedenjakaja, jonka perusteella 1970-luvun ympäristökeskustelu yhä selvemmin jakaantuu kahteen valtavirtaukseen. Vaatimus, joka tuntuu itsestään selvältä, ei ole tosiasiassa lainkaan itsestään selvästi toteutunut. Sille vastakkaisena linjana on kaikkien yhteiskunnallisten kriisi-ilmiöiden yhä pahempi puurouttaminen yhteen, ja näiden kaikkien johtaminen viime kädessä ekologiasta. Hyvinkin merkittävät ympäristöongelmia tutkivat luonnontieteilijät ovat taipuvaisia tähän. Merkittävimpien kansainvälisten luonnonsuojelujärjestöjen tuella ilmestyvä aikakauslehti "Environmental Conservation" esimerkiksi julkaisi numerossa $1 / 77$ pääkirjoituksen otsikolla Kannattaako jäädä henkiin? Siinä otetaan lähtökohdaksi vuoden 1973 öljykriisi ja todetaan: "Sen jälkeen on yleisesti käynyt ilmi, että emme kykene hallitsemaan inflaatiota, pysäyttämään työttömyyden kasvua, hillitsemään sissien ja terroristien hyökkäyksiä, lopettamaan yksityisten henkilöiden ja instituutioiden korruptoitumista tai saamaan kansalaisia uskomaan, että nämä ongelmat eivät itsestään ota ja häviä." Kirjoitus käsittelee ympäristökriisiä, mutta survoo sen osoittimiksi sekasortoisen luettelon yhteiskunnallisia ristiriitoja, joita nykykapitalismissa esiintyy.

Commonerin ohjelma saa myös tukea. Sen ottavat lähtökohdakseen marxilaiset tutkijat, jotka ovat lisääntyvässä määrin ryhtyneet tutkimaan ympäristöongelmia. ${ }^{4}$ Lähtökohtana on historiallisen materialismin teoria, joka pitää tuotantoa yhteiskunnan ja luonnon vuorovaikutuksen perusprosessia. Tänä vuorovaikutuksen tutkimisessa on lähdettävä tuotantoprosessia hallitsevien lainmukaisuuksien eli kunkin tuotantotavan analyysistä.
Kapitalismin yhteiskunnan ympäristökriisin lähtökohdat on siksi löydettävä itse tuotantotavasta: "Luonnonympäristön kapitalistisen arvonlisäyksen erityiset muodot määräävät ympäristökriisin yhteiskunnalliset ehdot nykyisessä kapitalismissa. Nämä ilmenevät ennen kaikkea siten, että kapitalismille ominainen perusristiriita ilmenee yhä voimakkaammin myös välittömästi ihminen-ympäristö-keskinäissuhteessa." Tämä ddr-läisten taloustutkijoiden toteamus ei ole sinänsä kapitalismin ympäristökriisin määritelmä, mutta se antaa oikean metodologisen lähtökohdan ympäristökriisin analysoinnille: On tutkittava nimenomaan sitä, miten yhteiskuntamuodostumalle ominaiset peruslainmukaisuudet heijastuvat ihmisen ja ympäristön vuorovaikutuksen. Kapitalismissa tätä vaikutusta hallitsee yhä selvemmin yhteiskuntajärjestelmän ristiriitojen syveneminen.

Commonerin tutkimusohjelman mukaisesti käsitteeseen "ekologinen kriisi" on tehtävä olennainen täsmennys: kysymys on yhteiskunnan ja luonnon vuorovaikutussuhteen (vuorovaikutusprosessin) kriisistä. Koska vuorovaikutuksen aktiivinen, määräävä tekijä on yhteiskunta, joka tuotantoprosessin välityksellä kuluttaa luonnonympäristön elementtejä, on kriisin syyt etsittävä yhteiskunnallista tuotantoa määräävistä tekijöistä. Tarkastelun lähtökohdaksi on siis otettava luonnonympäristön määritteleminen taloudellisena kategoriana, yhteiskunnan taloudellisten lainmukaisuuksien alaisena. (Ja päinvastoin: Yritys tarkastella yhteiskuntaa ekologisena kategoriana, mitä edellä kutsuttiin "ekologismiksi",

3. B. Commoner, Ympyrä sulkeutuu, Jyväskylä 1972, ss. $12-13$.

4. Marxilaisia yleisesityksiä ovat mm.: J. K. Feodorov Yhteiskunnan ja luonnon vuorovaikutus, Pori 1974; I. P. Gerasimov (toim.), Man, Society and the Environment, Moskova 1975; Guy Biolat, Ökologische Krise?, Berliini 1974.

5. A. Leonhardt \& G. Speer, Umweltreproduktion im staatsmonopolistischen Kapitalismus, Berliini 1977, s. 32 . 
on tuloksetonta täsmälleen siksi, että vuorovaikutuksen todelliset määräävät tekijät sivuutetaan.)

\section{Kapitalismin talous}

ja ympäristö

"Luonnonympäristö on poliittisen taloustieteen kategoria ennen kaikkea siksi, että ulkoisten luonnonolosuhteiden tuottava kuluttaminen on aina sidoksissa tuotantovälineisiin ja siten tiet-

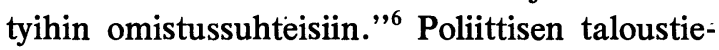
teen tehtävänä on löytää kapitalistisen yhteiskunnan taloudesta määräytyvät objektiivisesti vaikuttavat yhteiskunnalliset suhteet, jotka ovat yhteiskunnassa toimivien yksilöiden tahdosta riippumattomia. Marxin kehittelemään poliittisen taloustieteen kritiikkiin nojautuen on mahdollista tarkastella nimenomaan sitä, mihin yhteiskunnallisiin muotoihin luonnon eri elementtien tuottava kuluttaminen on kapitalismissa sidoksissa. Lähtökohdan tarkastelulle antaa ympäristön uusiutumisen vaatimus; tämä on edellytyksenä sille, että taloudellisen prosessin jatkuvuus on turvattu. Tuotannon laajeneminen ja tehostaminen vaarantaa ympäristön uusiutumisen luontaiset edellytykset. Tällöin osa yhteiskunnallista työtä on käytettävä ympäristön uusiutumisen turvaamiseen. Tämän luonnontieteelliset ehdot koostuvat siitä, että tunnetaan riittävän hyvin luonnonprosessit, joita tuotannossa käytetään hyväksi. Yhteiskunnalliset ehdot koostuvat siitä, miten voimavarat ohjautuvat.

Tavaroiden käyttöarvon ja arvon erottelu on olennainen. Tietyn tavaran käyttöarvo perustuu sen luontaisiin ominaisuuksiin, joiden perusteella se tyydyttää jotakin inhimillistä tarvetta. Arvon tavara saa vaihdossa, markkinoilla; arvon suuruuden määrää sen tuottamiseen välttämättömän yhteiskunnallisen työn määrä. Luonnonympäristön elementit, jotka ovat olemassa ilman että niiden ylläpitämiseksi on tehty työtä, ovat käyttöarvoja mutta niillä ei ole arvoa. Arvon ne saavat sen kautta, että niiden ylläpitäminen, niiden suojaaminen tuotannon seurauksilta edellyttää yhteiskunnallisen työn kuluttamista. Tarkastellessaan luonnonympäristön arvoa Leonhardt ja Speer kehittelevät mielenkiintoista käsitettä "metapotentiaali". Tämä viittaa niihin ympäristön elementteihin, jotka ovat tuotannon harjoittamisen ja tuottavuuden lisäämisen luonnonperustana, mutta joiden esiintyminen on luontaista, yhteiskunnallisesta työstä riippumatonta. Käsite "ekologinen metapotentiaali" viittaa erityisesti niihin tekijöihin, jotka ovat sidoksissa elollisen luonnon toimintakykyyn.

Luonnonsuojelun olennainen aspekti on ekologisen metapotentiaalin ylläpitäminen (ja vastaavasti ympäristökriisin olennainen aspekti on ekologisen metapotentiaalin vaarantaminen). Tuotannon voimaperäistyessä tämä edellyttää tietyn "ekologisen infrastruktuurin", so. puhdistus- ja valvontalaitteiston olemassaoloa. Ekologisen infrastruktuurin ylläpitämiseen välttämättömän yhteiskunnallisen työn määrä on perustana tietyn yhteiskunnan ekologisen metapotentiaalin arvosuuruudelle. Kapitalistinen yhteiskuntamuodostuma perustuu tuotantovälineiden yksityisomistukseen. Tästä yksityisomistuksesta seuraa tuotannon yleisten edellytysten, myös ekologisen metapotentiaalin, hallinnan joutuminen omistavan luokan käsiin. Jokaisen tuotantovälineitä omistavan kapitalistin toiminnan määrää pääoman arvonlisäyksen pakko; pääoma voi olla olemassa vain jatkuvasti itseään lisäävänä arvona, jatkuvassa liikkeessä. Markkinoilla totetuva kilpailu eri pääomien kesken toteuttaa kapitalistisen talouden pakkolait ja pakottaa jokaisen yksityisen pääoman nostamaan tuottavuutta niin paljon kuin mahdollista. Mutta tästä seuraa ekologisen metapotentiaalin ylläpitämisen kannalta perustavanlaatuinen ristiriita: Luonnonympäristön uusiutumisen turvaaminen ja eko- 
logisen metapotentiaalin ylläpitäminen edellyttävät yhä laajempia rajoituksia ja suojelutoimenpiteitä, joiden toteuttaminen aiheuttaa kustannuksia ja on jokaisen yksityisen pääoman voittopyrkimyksen vastaista, tai jopa vaarantaa niiden mahdollisuuksia jatkaa toimintaansa pääomana. Tämä on erityisen selväå silloin, kun kansainvälisillä markkinoilla toimii kilpailevia yrityksiä, jotka selviytyvät ilman näitä rasituksia: Ei ole sattuma, että italialaisen Seveson kaupungin myrkytti sveitsiläinen yritys ja ruotsalaisen Teckomatorpin myrkytti tanskalainen yritys, tai että länsisaksalainen teollisuus siirtää vaikeimpia ympäristöongemia aiheuttavaa teollisuuttaan Etelä-Amerikkaan.

Kapitalismin ympäristökriisin lähtökohta on siis talousjärjestelmän peruslaeissa: Luonnonvarojen ja ekologisen metapotentiaalin hallinta alistetaan pääoman arvonlisäykselle; arvonlisäys taas asettaa tiukat rajoitukset sille, missä määrin ympäristön uusiutumisen vaatimuksia otetaan huomioon tuotannon yhteydessä. Nykyisellä valtiomonopolistisen kapitalismin kaudella valtion tehtäväksi tulee tämän ristiriidan sääntely. Täydellinen onnistuminen on kuitenkin mahdotonta, koska kyse on kapitalismin peruslaeista, koska yhteiskunnan ja luonnon välisen vuorovaikutuksen häiriintyminen seuraa kapitalismin perusluonteesta. ${ }^{?}$

\section{Voidaanko ympäristökriisi voittaa?}

Millä edellytyksillä ympäristökriisi voidaan voittaa? Kun lähtökohdaksi otetaan se, että kriisissä on kyse yhteiskunnan ja luonnon suhteen kriisistä, voidaan kysymys muotoilla toisin: Voidaanko yhteiskunnan ja luonnon vuorovaikutus: ta tietoisesti hallita? Tämän ehtona on yhtäältä yhteiskunnallisen toiminnan ohjaaminen ja toisaalta ekologisten lainmukaisuuksien hallitseminen niin, että niitä voidaan tietoisesti käyttää hyväksi elollisen luonnon tuottavuuden ylläpitämi- seksi ja lisäämiseksi. Onko näitä ehtoja periaatteessa mahdollista täyttää?

Ekologiset liikkeet vastaavat tähän kieltävästi pérustellen väitettä - kuten esitettiin - sillä, että ekologian lait ovat periaatteessa esimerkiksi fysiikan tai kemian laeista luonteeltaan poikkeavia kokonaisvaltaisuutensa ja kattavuutensa vuoksi. Ihmisen yhteiskunnallisella toiminnalla ei tämän mukaan ole mahdollista muuntaa ekologisten järjestelmien toimintaa (periaatteessa samoin kuin on mahdollista puuttua fysikaalisten tai kemiallisten järjestelmien toimintaan). Tästä tehdään se johtopäätös, että yhteiskunnan eloonjäämisen ehto on organisoida kaikki toiminnot "ekologian periaatteiden" mukaan. ${ }^{8}$ Marxilaiset tutkijat vastaavat kysymykseen myöntävästi: Yhteiskunnallista kehitystä ja koko yhteiskunnan ja luonnon vuorovaikutusta on mahdollista hallitusti ohjata. Tämän edellytyksenä on historiallisen muutoksen toteuttaminen yhteiskunnallisissa suhteissa.

Marxilainen käsitys perustuu materialismiin. Ihminen kykenee käytännön välityksellä saamaan oikeata tietoa objektiivisesti pätevistä luonnon laeista, ja siten yhä paremmin käyttämään niitä hyväkseen. Teknologinen kehitys on olemukseltaan rationaalista luonnon eri prosessien hallintaa, joka perustuu yhä parempaan luonnon tuntemukseen ja hyödyntämiseen. Ekologian lait ovat tosin monimutkaisempia kuin fysiikan tai kemian lait, mutta periaatteellista eroa niiden välillä ei ole - siksi ei myöskään voi olla

7. Valtiomonopolistisen ympäristöpolitiikan mahdollisuuksia ja rajoja ei tässä ole mahdollista tarkastella lähemmin. Aihetta ovat käsitelleet $\mathrm{mm}$. Guy Biolat, mt., Leonhardt \& Speer, mt. sekä useat artikkelit kokoelmassa Ökologie - ökonomische und politische Aspekte des Umweltschutzes, Marxismus Digest 2/1977.

8. Ehkä pisimmälle ohjelman muotoon laadittu esitys on Ecologist-lehden vuonna 1972 julkaisema laaja artikkeli Blueprint for Survival (eli "eloonjäämisen ohjelma"); julkaistu suomeksi: Vielä voimme pelastua, tiedemiesten manifesti aikamme ihmisille, Helsınki 1972. 
periaatteellista ristiriitaa teknologian ja elollisen luonnon periaatteiden välillä. Teollisuuden ja teknisen kehityksen aiheuttamat haitat johtuvat historiallisista (tiedollisista) ja yhteiskunnallisista rajoituksista, jotka estävät tuotannon rationaalisen kehittämisen. Pitäessään tiedettä ja teknologiaa sinänsä pahana ja hylättävänä "'ekologistinen" ajattelu on irrationaalista. Ongelmana on teknologian ja tieteen yhteiskunnallinen käyttö, ei niiden pahuus tai hyvyys "sinänsä".

Tällä hetkellä maapallolla on rinnakkain kapitalistinen ja sosialistinen järjestelmä. Sosialistisissa maissa on sosialistinen vallankumous jo suoritettu, on kumottu yksityisomistukseen perustuva tuotantojärjestelmä ja siirrytty talouden hallitun kehityksen kauteen. Siksi on oikeutettua sanoa, että sosialistisissa maissa ei vallitse ympäristökriisi samassa mielessä kuin kapitalismissa: Ei ole peruuttamattomia, tuotantojärjestelmän perusperiaatteista seuraavia ristiriitoja yhteiskunnallisen tuotannon ja luonnonympäristön uusintamisen vaatimusten välillä.

Tämä ei tietenkään merkitse sitä, ettei sosialistisilla mailla olisi ympäristöongelmia, jotka ovat hyvinkin vaikeita ja joiden ratkaiseminen vaatii suuria ponnistuksia. Ongelmia kärjistävät mm. kapitalismin perintö, joka on useissa maissa vielä erittäin lähellä; sodan aiheuttamat vauriot; imperialismin hyökkäysuhan aiheuttama puolustusjärjestelmän ylläpito, joka rasittaa tavattomasti koko taloutta sosialistisissa maissa; yksityisten jopa johtotehtävissä toimiviẹn henkilöiden kapea-alaiset ja individualistiset asenteet, jotka voivat johtaa vastuuttomuuteen ja yhteiskunnallisten normien laiminlyöntiin jne. Lisäksi ympäristövaurioiden torjumiselta puuttuu monessa tapauksessa vielä tiedolliset ja tekniset edellytykset, eikä sosialismiin siirtyminen sinänsä automaattisesti ratkaise näiden puuttumista. ${ }^{9}$

Olennaista on kuitenkin se, että sosialistisissa maissa ei ole ongelmien ratkaisun tiellä sellaisia yhteiskunnallisia lainalaisuuksia, jotka olisivat ristiriidassa ratkaisun kanssa. Siksi suunta on koko ajan positiivinen, ympäristönsuojelun entistä paremman toteuttamisen suunta; kapitalistisissa maissa suunta on päinvastainen. ${ }^{10}$

Ympäristökriisin torjuminen on ajankohtaista tässä ja nyt. Mitä täsmällisemmin osoitetaan, että ongelmien tieteelliset ja tekniset ratkaisut ovat käden ulottuvilla, sitä tehokkaammin raivataan tieltä myös ratkaisujen yhteiskunnallisia rajoituksia. Tämä on varmasti myös Suomen kansallispuistokeskustelun yksi tulos: Joskin metsäyhtiöiden ja suurmaanomistajien "teon propaganda" suojeluesitystä vastaan saattaa välittömästi johtaa toivottuun tulokseen, niin pidemmällä tähtäimellä se nostaa yhä voimakkaammin esiin kysymyksen: Millä oikeudella tämä yhteisten, välttämättömien vaatimusten torjuminen tapahtuu?

Kansainvälisesti ekologisen kriisin voittaminen on sidoksissa sen myönteisen kehityksen jatkamiseen ja syventämiseen, jonka käänne kylmän sodan kaudesta rauhanomaisen rinnakkainelon kauteen on toteuttanut. Keskeisenä tavoitteena on pidettävä varustelumenojen supistamista ja aseistariisuntaa. Vertailu ympäristönsuojeluun käytettyjen varojen ja varustelumäärärahojen välillä osoittaa, että ympäristönsuojelun toteuttamisen ei tarvitse hidastua varojen puutteen vuoksi: Esimerkiksi USA:ssa ovat ympäristöviranomaiset arvioineet, että ympäristönsuojelumenot vuosina 1971-1980 tulevat olemaan yh-

9. Useissa marxilaisten tutkijoiden teoksissa on arvioitu tarkemmin niitä muotoja, joita ongelmat sosialismissa saavat: mm. Lutz Maier (toim.), Allgemeine Krise des Kapitalismus, Berliini 1976, ss. 128-133; Hans Mottek, Umweltschutz - ökonomisch betrachtet, teoksessa K. Lohs \& S. Döhring (toim.), Im Mittelpunkt der Mensch, Berliini 1975; A. Bauer \& H. Paucke, Umweltprobleme in der Sicht des historischen Materialismus und bürgerlicher Weltmodelltheorien, Deutsche Zeitschrift für Philosophie 24 (1976): 783-798.

10. Bauer \& Paucke, (mt.) toteavat, että sosialismissa ympäristöongelman ratkaiseminen "on sopusoinnussa sosialistisen tuotannon objektiivisten tavoitteiden kanssa". 
teensä 287 miljardia dollaria. YK:n arvioiden mukaan lähes sama summa kulutettiin maailmassa sotavarusteluun vuonna 1972 yhden ainoan vuoden aikana (250 miljardia dollaria). ${ }^{11}$ Uusi merkittävä kansainvälinen kehityssuunta on sitoutumattomien maiden aloitteesta YK:n yleiskokouksenkin hyväksymä tavoite uuden kansainvälisen taloudellisen järjestyksen vakiinnuttamisesta, mikä merkitsisi siirtomaakaudelta periytyvien imperialismille ominaisten riisto- ja riippuvuussuhteiden purkamista maiden välisistä suhteista.

Ei ole mikään sattuma, että kansainvälinen rauhanliike on ottanut ympäristöongelmat konferenssiensa käsittelyjärjestykseen vakinaiseksi osaksi. Myös kansainvälisesti vahvistuu siten kaikkien edistyksellisten voimien tukemana rintama, joka voi raivata tieltä ympäristökriisin ratkaisua vaikeuttavat yhteiskunnalliset rajoitukset.

\section{Ympäristökriisi Suomessa}

Kansallispuistokomitean esityksen saama vastaanotto ei maassamme ole mikään satunnainen tapahtuma. Pikemminkin se on johdonmukainen osa kehityksessä, joka on tapahtunut ympäristönsuojelussa 1970-luvun aikana.

Ympäristönsuojeluherätys ehti Suomeen 1960-luvun loppupuolella. Luonnonsuojelujärjestöjen toiminta aktivoitui. Vuosikymmenen vaihteessa istui joukko valtion komiteoita, jotka laativat suuren joukon tavoiteohjelmia ympäristönsuojelun toteuttamiseksi Suomessa (ehkä tärkeimpänä Vuoden 1970 ympäristönsuojelutoimikunta kolmine osamietintöineen). Tätä vaihetta maamme ympäristönsuojelun kehityksessä voisi kutsua ympäristönsuojeluinnostuksen ja optimismin kaudeksi. Keskeiseksi tavoitteeksi nousi virallisen ympäristönsuojeluhallinnon aikaansaaminen; tämä toteutui vuonna 1973, jolloin perustettiin sisäasiainministeriön ympäris- tönsuojeluosasto ja maa- ja metsätalousministeriön luannonvarainhoitotoimisto.

Samoihin aikoihin hallinnon perustamisen kanssa tapahtui kuitenkin muutos yleisessä ilmapiirissä. Vuosikymmenen vaihteessa vireille saatetut aloitteet ja esitykset alkoivat hajaantua komiteoiden sisäisiin ristiriitoihin, kadota loppumattomille lausuntokierroksille ja ruuhkautua byrokratian uumeniin. Pysähtyneitä ja vesittyneitä uudistusaloja voi luetella pitkän rivin: vesilain uudistaminen, ilmansuojelu- ja meluntorjuntalain säätäminen, ympäristörikosten saattaminen rangaistavaksi teoksi, rakennuslain uudistaminen ja rakennussuojelun tehostaminen, metsälain uudistaminen sekä - ehkä kaikkein dramaattisimpana - vuodelta 1923 periytyvän jo kauan sitten vanhentuneen luonnonsuojelulain uudistaminen.

Kaikki nämä uudistushankkeet olivat nousseet välittömästä tarpeesta tehostaa ympäristönsuojelua. Tavoitteista tinkiminen ja asioiden ruuhkautuminen johtui poliittisista ristiriidoista hallintoelinten piirissä. Mutta nämä ovat heijastumaa eri yhteiskunnallisten ryhmien vastakkaisista taloudellisista intresseistä. Ympäristönsuojelutavoitteiden tinkimisen taustalta löytyvät siis suomalaisen yhteiskunnan eri ryhmien taloudelliset edut.

Tavoitteiden tinkimisen kauden tapahtumista voi nostaa erityisasemaan vesiensuojelun ja vesihuollon rahoituskomitea -nimisen toimikunnan työn, joka valmistui vuosina 1970-1971. Komitea esitti ensinnäkin, että teollisuuden puhdistusvelvoitteet (ja siten rahoitusvelvoitteet) mitoitetaan olennaisesti alhaisemmaksi kuin yhdyskuntien, vaikka teollisuus vastaa noin $75 \%$ :sta vesistöjen kuormituksesta. Toiseksi komitea esitti työtätekeviltä kerättävän jätevesimaksun käyttöönottoa yhdyskuntien vesiensuojelukustannusten peittämiseen. Uutta tämän rahoituskysymyksiä (ja siten välittömiä taloudellisia etu-

11. L. Maier (mt.), s. 133. 
ja) käsitelleen komitean esityksessä oli se, että suurteollisuuden tavoitteet kirjattiin komiteamietintöön.

Rahoitus on ollut keskeinen kysymys siirryttäessä 1970-luvun puolivälin tienoilla kolmanteen, tavoitteiden romuttamisen kauteen. Avoimin ja tavallaan kyynisin osoitus tavoitteiden romuttamisesta oli vesihallituksen asettama komitea, joka kantoi nimeä "'Vuoden 1975 vesiensuojelutoimikunta". Komitean tehtävänä oli karsia jo aiemmin liian alhaisiksi määriteltyjä vesiensuojelutavoitteita. Lisäksi komitean esityksiin sisältyy järjestelmä teollisuuden vesiensuojeluinvestointien tukemiseksi valtion varoin halpakorkoisilla luotoilla ja jopa suoranaisilla avustuksilla. Järjestelmä on otettu käyttöön siitä huolimatta, että teollisuuden omienkin arvioiden mukaan jopa $90 \%$ prosessiteknisistä (lähes kaikista) vesiensuojeluinvestoinneista lisää laitoksen tuottavuutta ja on siten ainakin osittain taloudellisesti kannattavia. Osuvampi nimitys kyseiselle toimikunnalle olisikin ollut "Vuoden 1975 vesien pilaamisen toimikunta".

Vesiensuojelun alalla on päädytty tilanteeseen, jossa teollisuudella on mahdollisuus saada huomattavaa tukea vesiensuojeluinvestoinneille, mutta siitä huolimatta niitä ei panna toimeen. Vesistöjen pilaantuminen on lisääntymään päin. Vesiensuojelu on hyvin konkreettisesti törmännyt suomalaisen kapitalismin talouden kriisikehitykseen. Kyseessä on ympäristökriisin, yhteiskunnan ja luonnon vuorovaikutussuhteen kriisin ilmentymä. Samaa osoittaa kansallispuistoesityksen kohtalo: Myös sen kohdalla luonnontieteellisesti perustellut ja toteuttamiskelpoiset esitykset ovat törmänneet luonteeltaan yhteiskunnallisiin rajoituksiin.

Maassamme on kuitenkin nähtävissä myös se tekijä, joka valmistelee tietä ympäristökriisin ratkaisemiselle, ja jonka itse kriisin kärjistyminen nostaa esiin. Yhteiskunnalliset kriisit ilmenevät aina ihmisten ja ihmisryhmien etujen välityksellä. Tämä pätee myös ympäristönsuoje- luun. On yhä selvemmin havaittavissa, että syntyy edellytyksiä myös voimien kokoamiselle toimintaan ympäristön tuhoutumista vastaan. On syntynyt elinympäristöä puolustavia liikkeitä. On saavutettu myös voittoja:

Paremman elinympäristön puolesta toimivat liikkeet, joista kokemuksia on lukuisilta paikkakunnilta ympäri maata, käynnistyvät usein melko satunnaisesti ja ovat tyypillisiä "yhden asian liikkeitä", jotka lopahtavat kun kohteena oleva asia ratkeaa. Olennaista on, että liikkeet nojautuvat tavallisen työtätekevän väestön etuihin. Tästä ne voivat viime kädessä saada voimansa. Siksi on esimerkiksi kansallispuistokeskustelun yhteydessä äärimmäisen tärkeää erottaa toisistaan ristiriitaiset intressit, joihin suunnitelmaan kohdistettu kritiikki pohjaa. Taistelu työttömyyden torjumisen puolesta on mahdollista yhdistää luonnonsuojeluliikkeen kanssa yhdensuuntaiseksi vaatimusliikkeeksi; ja jos tätä liittoa ei kyetä toteuttamaan, luonnonsuojeluvaatimuksilta katoaa voima. Edistyksellisen luonnonsuojeluliikkeen ero ekologistisiin liikkeisiin, jotka myös voivat olla yhteiskunnallisesti aktiivisia - aina vaaliosanottoa myöten - kiteytyy juuri tähän: On tukeuduttava ihmisten konkreettisiin etuihin siinä, missä ekologismi vaatii "uutta arvojärjestelmää", ja on toimittava konkreettisten yhteiskunnallisten tavoitteiden puolesta siinä, missä ekologismi rakentaa malleja uudesta ennennäkemättömästä ihmemaailmasta. ${ }^{12}$

12. Kansainvälinen taantumus on todennut voivansa käyttää hyväkseen irrationaalisia ekologialiikkeitä; niinpä mm. Tukholmassa vuonna 1972 järjestetyn YK:n ympäristönsuojelukonferenssin lukuisista rinnakkaistilaisuuksista osaa oli rahoittamassa säätiöitä, joilla on suoria yhteyksiä CIA:n kanssa. (Dagens Nyheter 23.7.1972; kts. myös Y. Haila, Ympäristönsuojelun poliittisuus, teoksessa A-R. Wallin (toim.), Tukholman ympäristökonferenssin varjosta, Helsinki 1973.) 


\section{Ympäristökeskustelun tehtävistä}

On kai selvää, että ympäristönsuojelukeskustelun tulee auttaa ongelmien ratkaisua: On kohdennettava ne osat yhteiskunnan ja luonnon vuorovaikutuksessa, joissa ristiriidat kärjistyvät, analysoitava tämän syyt ja löydettävä keinot ristiriitojen voittamiseksi. Yhteiskunnan ja luonnon vuorovaikutus leikkaa tavalla tai toisella kaikkia yhteiskunnallisen toiminnan aloja. Siksi ympäristöongelmien hahmottaminen yhtenä kokonaisuutena on vaikeaa; Ongelmien eri aspektit ulottuvat ilmakehän muutoksista rakennussuojeluun, metsätaloudesta korttelipuistoihin ja mineraalivaroista pakkaus- ja jäteongelmiin. Esitän seuraavassa tutkimuksen ja keskustelun kohteeksi kolme vuorovaikutusaluetta. Ne eivät muodosta systemaattista kartoitusta vuorovaikutuksessa ilmenevien ongelmien eri puolista. Tavoitteena on etsiä oikeaa lähestymistapaa ympäristönsuojelutyön kehittämiselle:

Ensinnäkin: On olennaista nähdä ympäristöongelmat konkreettisina, materiaalisina häiriöinä yhteiskunnan ja luonnon vuorovaikutuksessa; on siis olennaista määrittää ne objektiiviset luonnon lainmukaisuudet, joihin ongelmat perustuvat. Tämä on (pääasiassa) luonnontieteellisen ja teknisen tutkimuksen tehtävä. Ekologia on luonnontieteistä keskeisin, koska se tutkii elollisen luonnon kokonaisprosesseja, mutta myös muut luonnontieteellisen perustutkimuksen haarat ovat välttämättömiä. Ekologian asema muiden luonnontieteiden rinnalla on ekologisten katsomusten myötä noussut keskusteluun. Ekologia ei varmasti tieteenalana ole muista poikkeava; sen sisällön määrää tutkimuskohteena oleva objektiivisen todellisuuden osa. Mutta jos tutkimuskohde ulotetaan koskemaan ihmisen ekologiaa, so. yhteiskunnan suhdetta elolliseen luontoon, ongelmanasettelut laajenevat. Mm. neuvostoliittolaiset filosofit Katsura ja Novik ovat esittäneet näkemyksen, että ekologia (ja laajemmin koko biologia) on luonnontieteistä tällä het- kellä kaikkein voimakkaimmassa kehitysvaiheessa ja voi muodostua tieteellisen kehityksen dynaamiseksi haaraksi. ${ }^{13}$

Toiseksi: Yhteiskunnan ja luonnon vuorovaikutuksella on yhteiskunnallinen luonne, siksi myös ongelmat ovat olemukseltaan yhteiskunnallisia. On täsmennettävä käsitystämme ympäristön tuhoutumiseen johtavista yhteiskunnallisista mekanismeista - tällöin on tutkittava sekä ihmiskunnan historian yleisiä kehityspiirteitä että tietyn talousjärjestelmän taloudellisia lakeja. On etsittävä ongelmien ratkaisemiseen kykeneviä yhteiskunnallisia voimia. Olennaista on erityisesti löytää keinot yhdistää toisiinsa työtätekevien välittömät edut, taistelu niiden puolesta, sekä ympäristöongelmien ratkaiseminen. Tästä kehittyvä luonnonsuojeluliike saa liikevoimansa.

Kolmanneksi: On tukeuduttava ihmiskunnan edistyksellisen ajattelun koko perintöön. Sen perustana on materialismi ja materialistinen optimismi: vakuuttuneisuus siitä, että ihminen kykenee hankkimaan luonnosta oikeata tietoa ja toimimaan tämän mukaisesti. Eri tieteenalojen ja materialistisen maailmankatsomuksen historia on osoitus inhimillisen tiedostuksen kehityksestä, ei viivasuorasti, vaan mutkitellen ja polveillen. Oikean tiedon kriteerinä on yhteiskunnallinen käytäntö. Yhteiskunnan ja luonnon vuorovaikutuksen ongelmat on periaatteessa tiedostettu. Vuorovaikutuksen tietoisen hallinnan edellytykset ovat ihmiskunnan käden ulottuvilla.

13. A. Katsura \& Novik, The Study of the Biosphere and Human Ecology, Social Sciences VIII (1977), no 4, ss. $171-181$. Perusteluksi Katsura ja Novik esittävät näkemykselleen sekä ihmisen ekologian tutkimuksen käytännön haasteet että biologian alalla saavutetut huomattavat teoreettiset edistysaskeleet, joita on myös lähitulevaisuudessa odotettavissa. 